Pamiętnik Literacki 2019, 2, s. 133-154

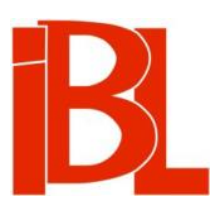

\title{
Artykuł Theodora Westrina o oblężeniu Jasnej Góry przez wojska Karola X Gustawa w 1655 roku, opublikowany w Szwecji w 1904 roku
}

Oprac. i tł. Filip Mazurkiewicz 
Pamiętnik Literacki CX, 2019, z. 2, PL ISSN 0031-0514

DOI: $10.18318 / \mathrm{pl} .2019 .2 .8$

\title{
ARTYKUE THEODORA WESTRINA O OBLĘ̇̇ENIU JASNEJ GÓRY PRZEZ WOJSKA KAROLA X GUSTAWA W 1655 ROKU, OPUBLIKOWANY W SZWECJI W 1904 ROKU
}

\author{
Opracował \\ FILIP MAZURKIEWICZ Uniwersytet Śląski, Katowice
}

Prezentowany tu tekst ${ }^{1}$ ukazał się w 1904 roku w „Historisk Tidskrift”, którego tytuł przełożyć można po prostu jako „Czasopismo Historyczne”. Jest to jeden z ważniejszych szwedzkich periodyków poświęconych historii ogólnej i dziejom ekonomii. Wychodzi nieprzerwanie od 1881 roku do dziś i, również nieprzerwanie, jest redagowany i wydawany przez Szwedzkie Towarzystwo Historyczne, które założono rok wcześniej.

Autor publikowanej tu rozprawy, Theodor Westrin (1850-1928), był szwedzkim historykiem i wydawca. W 1875 obronił doktorat na temat rewolucji angielskiej 1688 roku, a następnie został zatrudniony w Archiwum Królewskim, gdzie funkcjonował przez wiele lat. Współtworzył i współwydawał znaną szwedzką encyklopedię Nordisk familjebok. Napisał liczne prace o tematyce historycznej. Znany z dobrego i ciętego pióra, był członkiem Szwedzkiej Akademii Sztuk Pięknych - odpowiednika Szwedzkiej Akademii Nauk, powołanego do badań z zakresu humanistyki ${ }^{2}$.

Tekst Westrina nie jest elementem walki na polityki historyczne. Przed powstaniem tej pracy szwedzka legenda oblężenia Jasnej Góry nie istniała (później oczywiście także nie), samą zaś rozprawę postrzegać należy jako próbę przywrócenia elementarnej równowagi między faktami a mitami. Można sądzić, że konieczność podjęcia tej próby pojawiła się wraz ze wzrastająca ś światową sławą Henryka Sienkiewicza oraz z przyznaniem mu Literackiej Nagrody Nobla. Warto zauważyć, iż stało się to rok po ukazaniu się tekstu Westrina, w 1905. W tymże roku wyszła nadbitka, zapewne także w związku z owym wyróżnieniem. Literackie

1 Tytuł oryginału brzmi: Om Częstochowa klosters belägring af Karl X Gustafs trupper 1655 („Historisk Tidskrift”〈t. 24〉1904). Tekst ten był podstawą niniejszego przekładu. Rok później, w 1905, ukazała się w Sztokholmie nadbitka wraz z uzupełnieniem. Wersja z 1904 r. obejmuje dodatkowo dwie reprodukcje rycin pochodzące z Nowej Gigantomachii A. Kordeckiego (zob. A. Kor de cki, Pamiętnik oblężenia Częstochowy 1655 r. Przeł. J. Łe pkowski. Red. J. Maj d e cki. Częstochowa 1991; pierwsza przedstawia klasztor jasnogórski, druga zaś „ikonę jasnogórską według legendy namalowana przez Łukasza Ewangelistę i przechowywaną w klasztorze częstochowskim” 〈ibidem, s. 302〉), oryginał znajdującego się w Archiwum Królewskim listu przeora do generała B. Müllera oraz kopię tego listu z Nowej Gigantomachii (autograf Kordeckiego odbity z listu tegoż do Karola X Gustawa na podstawie oryginału przechowywanego w AK). Oba listy załączono w łacińskim oryginale.

2 Zob. H. H ofberg, Svenskt biografiskt handlexikon. Red. F. He urlin, V. Millqvist, O. Ruben s on. Wyd. 2. T. 2. Stockholm 1906, s. 713-714. Hasło to, jak widać, ukazało się jeszcze za życia Westrina, lecz trudno znaleźć jego dokładniejszy biogram. Przywoływany tu szwedzki słownik biograficzny, odpowiednik naszego PSB, nie został dotąd w całości zdigitalizowany. 
opracowania tematu walk o Częstochowę (autorstwa Sienkiewicza, ale również Józefa Ignacego Kraszewskiego - w Kordeckim. Powieści historycznej) przyćmiewają fakt, że główne źródła polskie stoją w pewnej sprzeczności ze szwedzkimi, a teksty beletrystyczne ignorują ustalenia historyków. Taka niezgodność nie jest zresztą niczym nadzwyczajnym i można by przejść nad nią do porządku dziennego, gdyby nie niezwykła pozycja Sienkiewicza, który długo był (a może nadal jest?) postrzegany nie tylko jako prozaik, lecz także jako autor prawdziwej, obowiązującej wizji historycznej. Adam Kersten w 1955 roku stwierdzał:

Przeszło 50 lat temu historyk szwedzki, Teodor Westrin, napisał małą rozprawę o oblężeniu Jasnej Góry. Studium to w zasadzie zapoczątkowało prace nowoczesnej historiografii nad tym tak ciekawym i tak powszechnie znanym wydarzeniem w historii Polski.

Od czasu opublikowania artykułu Westrina ukazała się tylko jedna obszerna praca monograficzna opisująca obronę klasztoru jasnogórskiego. Było to do niedawna, pomijając całą plejadę artykułów publicystycznych, popularnonaukowych i propagandowych, jedyne polskie opracowanie tego tematu. Dopiero ostatnio, w r. 1957, ukazały się dwa studia oparte na materiałach źródłowych. Jednak wszystkie te prace nie wyczerpały zagadnienia i brak dotąd pełnej naukowej syntezy historii obrony i oblężenia Jasnej Góry.

Nie jest to przypadkiem. Wydaje się, że przy obecnym stanie badań na rzeczywistą synteze jest jeszcze o wiele za wcześnie. Tak się na ogół zdarza, że okresy i fakty najpowszechniej znane w społeczeństwie posiadają bardzo ubogą literaturę naukową ${ }^{3}$.

Rozprawa Westrina prawdopodobnie nie zainteresuje historyków, choć byłoby to pożądane. Wiele pożytku mogłaby przynieść także uważna jej lektura dokonana przez znawców literatury staropolskiej, gdyż Westrin wykazuje pewną niedbałość wobec polskich źródeł. W niniejszym przekładzie staraliśmy się prostować nieścisłości oraz uzupełniać przypisy występujące $\mathrm{w}$ oryginale. Tekst Westrina wydaje się najciekawszy dla badaczy i - szerzej czytelników Potopu. Rozprawa wchodzi w dialog z ugruntowaną w naszym myśleniu wizją Sienkiewiczowską, podważa ją, redefiniuje, czasem całkowicie jej zaprzecza. Nie było „kolubryny”, bo ciężkich dział król Müllerowi odmówił. Szwedzi to nie Szwedzi - wedle Westrina pod Częstochową nie pojawił się ani jeden oficer szwedzki, a najprawdopodobniej też w ogóle żołnierze tej narodowości. Oblegający więc nie dość, że - przemarznięci - nie marzyli o Wigilii w Smolandii, gdyż nie stamtąd przybyli, ale na dodatek (o czym jeszcze będzie mowa)

3 A. Kerste n, Geneza „Nowej Gigantomachii”. „Annales Universitatis Mariae Curie-Skłodowska”, Sectio F: „Nauki Filozoficzne i Humanistyczne” t. 10 (1955), s. 1-2. Ciekawe, że tekst ten pochodzi z 1955 r., a przywoływane są w nim prace z 1957. Dobre to miejsce, by przypomnieć bibliografię interesującego nas tu zagadnienia: S. Kobierzycki: Obsidio Clari Montis Częstochoviensis, deiparae imagine a divo Luca depictae in regno Poloniae celeberrimi, ab exercitu Suecorum duce Burchardo Mellero. Dantisci [Gdańsk] 1659; Obsidio Clari Montis. Oblężenie Jasnej Góry. Przeł. K. Chmielewska, E. Rygał. Wyd., wstęp, przypisy A. J. Zakrzewski. Kraków 2007. Oblężenie Jasnej Góry Częstochowskiej. Pieśni dwanaście (anonimowy poemat heroiczny z drugiej połowy XVII w., wydany przez J. Czubka w 1930 r.). - O. Górka, Legenda a rzeczywistość obrony Częstochowy $w$ roku 1655. Warszawa 1957. - T. N o w a k, Obrona Klasztoru Jasnogórskiego $w$ roku 1655. Warszawa 1957. - A. Kersten: Pierwszy opis obrony Jasnej Góry w 1655 r. Studia nad „Nowa Gigantomachia” ks. Augustyna Kordeckiego. Warszawa 1959; Sienkiewicz - „Potop” - historia. Warszawa 1974. - W. Cza plińs ki, Glosa do „Trylogii”. Wrocław 1974. A. Korde cki, Pamiętnik oblężenia Częstochowy 1655 r. Przeł. J. Łe pkows ki. Red. J. Majd e c ki. Częstochowa 1991. - R. O c i e c z e k, „Oblężenie Jasnej Góry Częstochowskiej” - dzieło i autor. Kraków 1993 (propozycja atrybucji: S. Damalewicz). - Czasy potopu szwedzkiego w literaturze polskiej. Red. R. O c i e c z e k, przy współudz. B. Mazurkow ej. Katowice 2000. - M. C etw ińs ki, „Nowa Gigantomachia”. Przyczynek do barokowej wizji dziejów. „Prace Naukowe Akademii im. Jana Długosza w Częstochowie”. Seria: „Zeszyty Historyczne” z. 10 (2009). 
obchodzili wówczas święta 10 dni później niż oblężeni Polacy. Takich demitologizujących rewelacji znajdzie czytelnik w rozprawie bardzo wiele.

Jest ona interesująca także tam, gdzie odsyła do szwedzkich źródeł - dotyczy to przede wszystkim kroniki Samuela von Pufendorfa ${ }^{4}$ oraz zachowanych listów, które krążyły między głównymi aktorami dramatu: hrabią Janem Weyhardem Wrzeszczowiczem, generałem Burchardem Müllerem von Lündenem, marszałkiem Arvidem Wittenbergiem, królem Karolem X Gustawem i księdzem przeorem Augustynem Kordeckim. Szczególnie ciekawie w świetle zachowanej korespondencji jawi się generał Müller - jako świetny retor i cięty ironista, ale także autoironista, mocno odbiega od nakreślonego przez Sienkiewicza obrazu postaci prostaczka zazdroszczącego wysoko urodzonym. Ksiądz Kordecki z natchnionego męża opatrznościowego staje się zaś pod piórem szwedzkiego archiwisty sprawnym politykiem i odważnym, a zarazem sprytnym przywódcą, który potrafi stawić czoła nie tylko oblegającym, lecz także silnej opozycji wewnętrznej. Westrin pisze rzeczowo, w relacjach na temat przeszłości umie odróżnić fakty od fikcji i dobrze wie, iż ta druga bywa narzędziem polityki. Rozumie, że propaganda historyczna jest stara jak świat i że posługuje się rozmaitymi chwytami, nie wyłączając „widocznych” cudów.

Warto też zwrócić uwagę na podwójne lokalizowanie wydarzeń w czasie, występujące w kilku miejscach tekstu. Bierze się ono stąd, że w Rzeczypospolitej kalendarza gregoriańskiego używano od 1582 roku, więc obowiązywał on tam już w trakcie najazdu szwedzkiego - natomiast w Szwecji dopiero od 1753 roku. Kraje protestanckie wprowadzały reformę papieża Grzegorza XIII z opóźnieniem. Dlatego datowanie Westrina, jeśli wywiedzione jest ze szwedzkich dokumentów (a tak dzieje się na ogół), opiera się na starym porządku, a podwójne pojawia się tylko wtedy, gdy Westrin porównuje dokumenty szwedzkie $z$ polskimi.

Do swej rozprawy dodaje też tekst listu księdza Kordeckiego do generała Müllera, który odnalazł w Archiwum Królewskim, i zestawia go z wersją umieszczoną w Nowej Gigantomachii pióra jasnogórskiego przeora. Listy mocno się od siebie różnią, a charakter tych różnic jest przedmiotem analizy archiwisty. Do tekstu niniejszego dołączamy obie wersje dokumentu po łacinie (tak jak Westrin) i uzupełniamy je o ich polskie przekłady, które poddane zostały modernizacji. Wyróżnienia, kursywy - jeśli nie zaznaczono inaczej - pochodzą od autora rozprawy. Zachowano też na ogół formę stosowanych przezeń przypisów i innych odwołań. Cytaty $z$ listów pisanych po niemiecku zostały przytoczone w tekście głównym w oryginale wraz $\mathrm{z}$ tłumaczeniami, których autorem jest Wacław Miodek. Tak samo postąpiono $\mathrm{z}$ cytatami łacińskimi.

Filip Mazurkiewicz

THEODOR WESTRIN

\section{O OBLEZŻENIU KLASZTORU CZESTOCHOWSKIEGO PRZEZ WOJSKA KAROLA X GUSTAWA W 1655 ROKU}

W dzisiejszej rosyjskiej Polsce, w guberni piotrkowskiej, blisko granicy śląskiej, około 100 kilometrów na północny zachód od Krakowa, opodal miasta Częstochowa, leży klasztor o tej samej nazwie, utworzony w regule paulińskiej. Określa się

4 S. v on Pufend orf, Siedem ksiag o czynach Karola Gustawa, króla Szwecji. Przeł., oprac., wstęp W. Krawczuk. Warszawa 2013. Pierwodruk: De rebus a Carolo Gustavo Sueciae rege gestis. Norimbergae 1696. 
go także od nazwy góry, gdzie spoczywa - Jasna Góra (po niemiecku Klarenberg, po łacinie Clarus Mons). Założony został przez księcia Władysława Opolczyka [Opolskiego], który w 1382 roku, jako ówczesny polski „prorex”, polecił umieścić tam portret Marii, według legendy namalowany przez ewangelistę Łukasza. Uczyniło to klasztor niezmiernie popularnym i zamieniło Częstochowę w „polskie Loreto" - miejsce najczęściej wybierane jako cel pielgrzymek. Wielokrotnie wystawione na ataki obcych wojsk, miejsce owo za panowania Władysława IV zostało otoczone murami obronnymi i innego rodzaju fortyfikacjami. W wyniku tego wzrosła jego zdolność do obrony, co w 1655 roku mnisi pod przewodnictwem przeora Augustyna Kordeckiego wykorzystali przeciw wojskom Karola X Gustawa, które przez dłuższy czas oblegały klasztor na próżno.

W pracy Svenska bilder i polska vitterheten (Szwedzkie obrazy w polskiej literaturze pięknej), która znalazła się w poprzedniej książce pana Alfreda Jensena, pisze on o Nowej Gigantomachii Kordeckiego, wydanej w 1657; tam po łacinie sportretowano owo oblężenie, którego niepowodzenie było poważną [szwedzka] porażką militarna, dla Polaków zaś - „Zwycięstwem moralnym” o bardzo zasadniczych następstwach. Wedle słów Jensena nie ma w tym ani trochę przesady, że epizod ten „w gruncie rzeczy stał się skała, o którą rozbiła się kontynentalna (europejska) polityka Karola X Gustava”. Pan Jensen wyraża zdumienie, że wydarzenie owo ani jednym słowem nie jest wspomniane przez szwedzkich historyków, szczególnie że mieli oni dostęp do pracy Kordeckiego. Przypuszcza też autor rozprawy, iż wynikło to „nie wyłącznie $z$ nieznajomości języka” - formułuje więc pod ich adresem oskarżenie, że zachowują oni milczenie, by nie sprzeniewierzyć się „honoro-

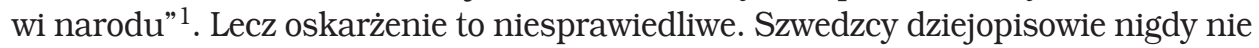
usiłowali zamieść klęski pod dywan, a już zwłaszcza ciosu, jaki przywiedziony do ostateczności polski naród zadał najeźdźcom prowadzonym przez Karola Gustawa. Nie ukrywali też bohaterskich zwycięstw Stefana Czarnieckiego. Powodem milczenia tutejszych uczonych na temat Częstochowy zapewne był fakt, że pierwszy kronikarz Karola Gustawa, Samuel Pufendorf, w swym obszernym dziele, które służyło wszystkim późniejszym badaczom za przewodnik ${ }^{2}$, poświęca owemu wydarzeniu zaledwie parę słów. Poza tym historia szwedzkiego oreża pozostaje słabo opisana, jeśli nie dotyczy czynów, których król dokonał osobiście.

Pufendorf powiada, że generał porucznik [Burhard] Müller „bardzo chciał” wziąć Częstochowę, a ponieważ nie mógł przekonać mnichów, by przyjęli oni szwedzki garnizon, postanowił sięgnąc po rozwiązania militarne i polecił sprowadzić dwa potężne działa $z$ Krakowa. Lecz król zakazał tego typu rozwiązań, ponieważ Ipo pierwsze] zimowe oblężenie osłabiłoby armię, a po wtóre, posunięcie takie mogło zniechęcić przesądny naród [polski], bardzo szanujący owo miejsce, do Szwedów ${ }^{3}$.

Relacja ta, zawierająca szereg półprawd, przedstawia całkowicie nieprawdziwy obraz zdarzeń. Müllera ukazuje się w niej jako człowieka przedsiębiorczego, król wygląda na zagubionego między racjami politycznymi i militarnymi i zabrania sto-

$1 \quad$ A. J en se n, Svenska bilder i polska vitterheten. Stockholm 1904. [Przypis tłum.].

2 S. von Pufend orf, Siedem ksiag o czynach Karola Gustawa, króla Szwecji. Przeł., oprac., wstęp

W. Krawczuk. Warszawa 2013. [Przypis tłum.].

3 Ibidem, s. 78. [Przypis tłum.]. 
sowania przemocy. Kto, mając te słowa przed oczami, może wyobrazić sobie, że chodzi tu o oblężenie, które ciągnęło się tygodniami i do którego rozpoczęcia rozkaz wydał sam monarcha? To oczywiste, że Pufendorf rozporządzał pełną - a przynajmniej dostateczna - „wiedzą o zdarzeniach”, pozostaje jednak niejasne, dlaczego tak wasko je zaprezentował i do tego w tak oszczednych słowach. Polacy ciskali w niego oskarżenia, że sprzeniewierza się on „podstawowemu obowiązkowi historyka, by zachowywać sprawiedliwość i bezstronność"4. Niewątpliwie Pufendorf, który był przecież oficjalnym kronikarzem, starał się ukazywać Karola Gustawa w jak najlepszym świetle, gdy tylko nadarzała się ku temu sposobność. Tak haniebne potraktowanie ataku na Częstochowę spowodowane było najprawdopodobniej właśnie tym, że król nie uczestniczył w nim osobiście; wszak historia pisana przez Pufendorfa odnosi się w pierwszej kolejności do czynów króla (jako „Res gestae”, „Thaten”5). Ponieważ przedsięwzięcie nie przyniosło rezultatów, dziejopis uznał je za niewarte szerszej wzmianki. Ranga owego wydarzenia dla Polaków najwyraźniej mu umknęła. Współczesna mu literatura, z wyjątkiem tekstu Kordeckiego, którego Pufendorf najprawdopodobniej nigdy nie miał przed oczami, a w tym i historia oblężenia (1659) spisana przez Stanisława Kobierzyckiego (kompilatora Kordeckiego) $^{6}$, nie czyni $z$ niego szczególnie wielkiej sprawy. Samuel Twardowski w swej obszernej kronice (wydrukowanej w 1681 r.) o „wojnie domowej” lat 16401650 mówi o tym wydarzeniu jedynie nawiasowo (przez 6 linijek!) ${ }^{7}$, w „Theatrum

4 J. U. Niemcewicz w swoich pamiętnikach (Pamiętniki czasów moich. [Lipsk] 1868, [s. 245]) pisze, że Pufendorf w swym przedstawieniu szwedzko-polskich zaszłości kierował się osobistą nienawiścią spowodowaną odmową, jaka otrzymał od polskiego dworu w odpowiedzi na starania o dożywotnią rentę oraz o tytuł historiografa. Zob. J e n s e n, op. cit., s. 160. [Odpowiedni fragment w zapiskach Niemcewicza brzmi: „Jeździłem do Drottingholmu, wiejskiego pałacu królewskiego, o milę od Sztokholmu. Z jakimże ściśnieniem serca widziałem tam potężne obrazy, wyrażające zwycięstwa Karola nad Polakami, wszystkie przesadzone, podług podania uprzedzonego przeciw nam Pufendorfa. Pufendorf udawał się najprzód do Polski, prosząc o tytuł historiografa i pensję, dalej do Danii; odrzucony od obu dworów, udał się do Szwecji, gdzie przyjęty i nagrodzony, osobistą zemstę wywarł na Polaków, ze zgwałceniem pierwszego obowiązku dziejopisa prawdy i bezstronności”. Porównanie tekstu Niemcewicza ze szwedzkim opracowaniem dowodzi, iż Jensen przytacza oryginał bardzo dokładnie (różnice tu widoczne wynikają wyłącznie z tego, że mamy w tym miejscu do czynienia $z$ przekładem z przekładu). Warto odnotować, że o Pufendorfie pisał też m.in. A. M i cki e w i c z (Literatura słowiańska. Kurs drugi. Przeł. L. Płos z e w s ki. Warszawa 1955, s. 46): „Słynny Pufendorf kazał nawet rytować słynne zmyślone oblężenia, liczne urojone miasta zdobyte rzekomo szturmem” - F. M.].

5 „Thaten” to tyle, co „czyny” lub „uczynki”. [Przypis tłum.].

6 S. Ko bi e r zy c ki, Obsidio Clari Montis Częstochoviensis, deiparae imagine a divo Luca depictae in regno Poloniae celeberrimi, ab exercitu Suecorum duce Burchardo Mellero. Dantisci [Gdańsk] 1659 [Przypis tłum.].

7 [S. Tw a r d ow s ki, Wojna domowa z Kozaki i Tatary, Moskwa, po tym Szwedami i z Węgry, przez lat dwanaście za panowania Najjaśniejszego Jana Kazimierza, króla polskiego toczaca się [...]. Calissi 1681, s. 162 - F. M.]. Cyt. za: J en s e n, op. cit., s. 91. [Westrin, wspominając o marginesowym potraktowaniu tematu oblężenia przez Twardowskiego, wyraźnie przytacza tu myśl wyrażoną przez J e n s e n a (ibidem), który pisał: „Sprawa oblężenia Częstochowy poruszona jest [przez Twardowskiego] jedynie przelotnie w punkcie trzecim czwartej części w następujących wersach:

Jedna się Częstochowa oprócz mu oparła,

Góra sławna od wieku, gdy w sobie zawarła

Dwieście dobrej piechoty i szlachty ściśniony

$\mathrm{W}$ takim gwałcie niemało, ufając w obrony 
Europaeum"8 zaś, które poza tym śpieszy opowiadać o ważnych i dziwnych wypadkach słowem i obrazem, nie wspomina o oblężeniu w ogóle. Przeciwnie Erik Dahlbergh. Ten, z pozoru przynajmniej, przywiązany był do myśli, że batalia jednak miała miejsce. W swych licznych notatkach wskazywał, iż wśród szkiców dokumentujących historię Karola Gustawa znajdował się też jeden zatytułowany Oblężenie Częstochowy przez szwedzkiego generała majora Müllera. Sam Dahlbergh zresztą ową akcję bojową przedstawił na rysunku i w postaci miedziorytu ${ }^{9}$. Jednakże w specyfikacji miedziorytów dokumentujących działania wojenne, jakich oryginały zostały przekazane dnia 16 VII 1695 do rak własnych Karola XI, nazwa Częstochowa się nie pojawia ${ }^{10}$.

Szwedzkich źródeł na temat przygotowań do oblężenia nie brakuje, choć jednocześnie nie dają one podstaw do pełnej ich prezentacji. W Archiwum Królewskim zachowały się listy, które Karol X Gustaw wymieniał z marszałkiem polowym Arvidem Wittenbergiem, porucznikiem Müllerem i generałem hrabią Janem Weychardem Wrzeszczowiczem ${ }^{11}$. Znajduje się tam też kilka dokumentów określonych zbiorczo jako Zdarzenia zwiazane z wojna polska Karola X Gustawa. Materiały te pozwalają na stworzenie następującego obrazu owych wydarzeń.

Kiedy jesienia 1655 zwycięski Karol X Gustaw świętował zdobycie polskich stolic, Warszawy i Krakowa (który poddał się 8 X [właśc. 17 X]), jednocześnie zaczynało się powstanie szlachty i chłopów przeciw Szwedom w województwach poznańskim, kaliskim, sieradzkim i łęczyckim, czyli w regionach zachodnich położonych blisko granicy ze Śląskiem, gdzie schronił się król Jan Kazimierz i gdzie zbierał wojska, aby wkroczyć w granice polskie i na nowo podjąc walkę ze swym pogromcą. W celu osłabienia ducha walki pośród „rebeliantów” - jak klasycznie, choć w nowoczesnym znaczeniu i w sposób raczej niejasny, nazywano Polaków walczących, ostatecznie, o swą niepodległość - na czele około tysiąca ludzi wysłano w głąb Wielkopolski oficera z Rzeczypospolitej (pochodzenia czeskie-

I wał mocny około: nade wszystko pieczą

Niebieskiej swej królowy [...].

Przytaczał więc faktycznie 6 linijek, choć cały fragment dotyczący tego tematu jest dłuższy - liczy około 40 wersów.]

8 „Theatrum Europaeum” było pismem historycznym poświęconym krajom niemieckojęzycznym. Ukazywało się w latach 1633-1738. Wyszły 23 woluminy in quarto. [Przypis tłum.].

9 Zob. Erik Dahlbergs egenhändiga förteckningar över relationer rörande polska och danska krigen 1655-1660 (Erika Dahlbergha własnoręczne notatki dotyczące spraw wojny polskiej i duńskiej 1655-1660). Archiwum Królewskie, rkps SE/RA/754/2/XI/2/34. Dalej Westrin powołuje się na tę pozycję, używając sformułowania „dziennik Dahlbergha” lub „zbiór Dahlbergha”. [Przypis tłum.]. Specyfikacja szkiców do historii Karola X Gustawa znajduje się w zbiorze Dahlbergha w Archiwum Królewskim. Natomiast miedzioryt przedstawiający oblężenie widnieje w pracy Kobierzyckiego. [W wydaniu dzieła S. Ko b i e r z y c k i e g o z 2007 r. (Obsidio Clari Montis. Oblężenie Jasnej Góry. Przeł. K. Chmielews ka, E. Ry gał. Wyd., wstęp, przypisy A. J. Zakrzews ki. Kraków 2007) miedzioryt ten nie jest reprodukowany - F. M.].

11 W Królewskich Rejestrach znajduje się instrukcja królewska dla B. Müllera z 22 X 1655, list do tegoż z 15, 16 i 13 XI, a także z 1 i 26 XII. Pośród zebranych pism do Jego Królewskiej Mości [tj. Karola X Gustawa - F. M.] figurują: list A. Wittenberga z 29 X, 15, 17 i 21 XI, wreszcie z 2, 4 i 17 XII, dalej mamy listy Müllera z 31 X, 2, 4 i 12 XI oraz z 16 i 25 XII 1655 i z 8 I 1656. Są też listy J. Wrzeszczowicza z 7 i 22 XI 1655. [W dalszej części tekstu Westrin powołuje się na te dokumenty - F. M.]. 
go, rzymskiego katolika, lecz zwerbowanego do szwedzkiej służby), generała Jana Weycharda, hrabiego Wrzeszczowicza ${ }^{12}$. Tam operował on wraz ze swym oddziałem we wrześniu i październiku. Zbrojnie odebrał „rebeliantom” Kościan (dziś Kosten w pruskiej prowincji poznańskiej), a następnie rzucił się na południowy wschód w stronę Wielunia, spod którego polska jazda wycofała się wcześniej ku granicy śląskiej, w czego wyniku szlachta się poddała, a tamtejsi mieszczanie przekazali hrabiemu klucze do miasta.

Wrzeszczowicz pozwolił wówczas odpocząc swej piechocie, sam zaś, nie wchodząc do miasta - gdzie później umieszczono liczący zaledwie 200 ludzi regiment księcia [von] Sachsena - jeszcze tej samej nocy wyruszył na czele jazdy w kierunku odległej o parę mil miejscowości Praszka. Tam pobił gwardię królewską oraz inne oddziały, dowodzone przez generała [Henryka] Denhoffa, jego samego i innych oficerów wziął zaś do niewoli. Następnie pociagnął w stronę zamku w Krzepicach, gdzie pozostawił cały regiment krajczego koronnego [Erika] Stenbocka, liczący 250 ludzi, oraz 100 ludzi własnej jazdy. Na koniec, 30 X, dotarł pod klasztor w Częstochowie, wobec którego był niegdyś hojnym donatorem, lecz, przywitany ogniem z dział i rusznic, wycofał się, podpaliwszy po drodze dwie stodoły. Odgłos klasztornych dział był jednak na tyle słyszalny, iż nikt nie uwierzył w podążające za wojskiem zapewnienia, że klasztor podda się w ciagu 4-5 dni.

Zanim informacje o ostatnich poczynaniach wojennych Wrzeszczowicza dotarły do królewskiej kwatery głównej w Krakowie - a być może też w związku z raportem generała, wysłanym jeszcze z Kościana (tuż po jego zajęciu), a mówiącym o tym, że rebelia będzie wzrastać, jeśli prędko nie zdławi się jej siłą - król wydał instrukcje (w znacznej mierze napisaną samodzielnie) skierowaną do porucznika Müllera von der Lühnena, stacjonującego w kwaterze głównej w Proszowicach, żeby ten rozproszył szlachtę i chłopów, którzy sprzymierzyli się w Wielkopolsce po to, aby stamtąd spokojnie szerzyć powstanie przeciw Szwedom. Pod swą komendę dostał porucznik tylko jazdę: regiment księcia Franza Erdtmana von Sachsena (,gar sehr abkommen [wymaszerować nie zwlekając]" - postanawia instrukcja w swej końcowej części ${ }^{13}$ ), regimenty pułkowników Hansa Kristoferssona von Beddekera i obu Engelów ${ }^{14}$, a do tego osiem kompanii kwarcianych i kilka [kompanii] dragonów ${ }^{15}$. Feldmarszałek Wittenberg, który znajdował się przy królu, żądał, aby Müller pociagnął z Krakowa na Częstochowę celem zabezpieczenia tego miasta, sądził bowiem, że będzie to proste do osiagnnięcia. Lecz król rozkazał Müllerowi wyruszyć natychmiast na Piotrków (150 kilometrów prosto na północ, w połowie drogi do Warszawy) i rozłożyć w tamtej okolicy 150 dragonów. Gdyby spokój został przywrócony, Müller nie potrzebowałby wszystkich dragonów i mógłby udać się do kwatery głównej, pozostawiając w terenie podzielone na kwarty regimenty Engelów i innych oficerów. Miejscowości Wieluń, Krzepice i Często-

31 VIII 1655 regiment hrabiego składał się z 10 kompanii (raport o liczebności zaczerpnięty z archiwum wojennego).

13 Karol X Gustaw, instrukcja dla B. Müllera, z 22 X 1655. [Przypis tłum.].

14 Było dwóch pułkowników o nazwisku Engel, Joachim i Hans.

15 Według raportu o liczebności z archiwum wojennego z 31 VIII 1655 regiment księcia von Sachsena składał się z 4 kompanii, Beddeker także wymaszerował z 4, obaj zaś Engelowie - z 10. 
chowa $^{16}$ (wszystkie leżące wzdłuż śląskiej granicy w podobnej od siebie odległości i znajdujące się około 80 kilometrów od zdobytego Piotrkowa) miał spróbować opanować.

Müller pomaszerował więc prosto na Piotrków, który major [Jan] Piron bohatersko obronił przed „rebeliantami”, i pozyskał tam informację o zajęciu Wielunia i Krzepic, co znaczaco ułatwiło generałowi zadanie. Nalegania Wittenberga, aby skoncentrować siły w Wielkopolsce i stanąc obozem w okolicach Sieradza, by stamtąd obserwować ruchy nieprzyjaciela w rejonie Częstochowy i śląskiej granicy, najprawdopodobniej w ogóle do Müllera nie dotarły, gdyż już wcześniej, mimo że brakowało mu piechoty i artylerii, ,zur Fortsetzung E. K. Maj:ts Befelich [w celu wykonania rozkazu Jego Królewskiej Mościl" postanowił on wyruszyć z Piotrkowa „in die jegend zwischen Siradia und Wielun zu Marchiren und die annoch widerspäntige Örter, in Sonderheit Czenstochow zu attacquiren [aby maszerować w okolice między Sieradzem a Wieluniem i zaatakować ciagle jeszcze broniące się miejscowości, szczególnie Częstochowę]".

Król z radością przyjął wiadomość, że Müller w swej „dewocji” postanowił zdobyć Częstochowę, lecz byłby też [jak pisał w liście] uszczęśliwiony, gdyby Müller, w zgodzie z dobrze mu znaną królewska „indolencja”, zechciał nie używać wobec klasztoru siły, gdyby znajdujący się tam ludzie poddali się bez walki, „ohne die Abwertung einiger extremität [bez skazy na naszej waleczności]". Müller - przeciwnie - powinien bronić tego miejsca przed zrujnowaniem. Ogólnie w przypadku gdyby nastapiło poddanie się, król pozostawiał generałowi wolną rękę, czy klasztor powinien zostać obsadzony przez szwedzki garnizon oraz, następnie, utrzymany [przezeń] ${ }^{17}$.

Müller natychmiast wprowadził swe zamiary w czyn. Przez Kaszewice, Szczerców i Krzepice ciągnął szybkimi marszami, chcąc wziąć Częstochowę szturmem lub układami. Aby przyspieszyć marsz, zatrzymał przy sobie tylko cztery kompanie z regimentu Beddekera, dwie Engela i jedną księcia von Sachsena. Pozostałe wraz z taborami odesłał do kwatery głównej. W Krzepicach połączył się z hrabią Wrzeszczowiczem i jego ludźmi: 300 pieszymi, kilkoma oddziałami konnymi i kilkoma dragonii. Było też osiem dział. Przed sobą generał posłał do Częstochowy trębacza z pismem, a sam przybył na przyklasztorne pola $8 \mathrm{X}$ z siłą - jeśli kompanię liczymy jako 100 żołnierzy - 1100 ludzi, z czego dwie trzecie stanowiła jazda i osiem dział.

Częstochowa nie była już wówczas jedynie miejscem zadumy religijnej spokojnych i nieszkodliwych mnichów. Klasztor miał w czterech rogach ufortyfikowane, oflankowane bastiony $z$ wysokimi, mocnymi murami oraz $z$ wysuniętymi do przodu głębokimi blankami zdolnymi skutecznie bronić przed szturmem. Mury uzbrojono licznymi 12-funtowymi, a być może jeszcze cięższymi, działami. Według danych Müllera garnizon liczył 400 „wahrhaftige soldaten [prawdziwych żołnierzy]”; niektórzy szacowali go i na 800 ludzi, co Müller uważał jednak za przesadę. Liczba obrońców zwiększyła się dodatkowo o znaczną grupę zbuntowanej szlachty; należeli do niej m.in. Aleksander Zamojski, Jan Jackowski, Sebastian Bogdański, Stefan Siemieński, Mikołaj Krzysztoporski i Zygmunt Moszczyński ${ }^{18}$ wraz z żonami,

16 Król pisze: „Schenstochofen”.

17 Karol X Gustaw, list do B. Müllera, z 15 XI.

1816 XI król rozkazał Müllerowi, by zezwolił on tym panom wraz z żonami, dziećmi, sługami i dobyt- 
dziećmi, famulusami i służbą, chroniącymi się w klasztorze przed wojskami szwedzkimi. Częstochowa stała się wtedy - szczególnie po tym, jak sąsiednie miejscowości padły łupem Szwedów - najważniejszym dla króla Jana Kazimierza punktem oporu w tej części Polski.

Zakonnicy nie chcieli słuchać trębacza i od razu przyjęli Müllera ogniem z dział oraz rusznic. Później przekonali generała do zawieszenia broni, które miało trwać aż do następnego dnia, kiedy planowano zawarcie układu. Układ ten mnisi - by użyć satyrycznego sformułowania samego Müllera - natychmiast „ratyfikowali”, podpalając kilka domów i stodół stojących zbyt blisko klasztoru. 9 XI Müller uderzył na leżącą nieopodal wieś Częstochówka, która, „, herausgeschossene Feuerkugeln [ostrzelana kulami ognistymi]", częściowo obróciła się w popiół, i usypał tam kilka baterii oraz rowów strzelniczych, by ostrzeliwać fortyfikacje. 10 XI przybył z klasztoru zakonnik $\mathrm{z}$ wiadomością, że dnia następnego na pewno zostanie zawarty układ. W jego ramach mnisi zaświadczyli o swej najgłębszej rewerencji i poddaniu się monarsze Szwecji, „którego czci całe królestwo”, pod warunkiem wszakże, że w mocy pozostanie list żelazny Wittenberga z $28 \mathrm{X}$, gwarantujący, że nie zostaną oni zaatakowani oraz że klasztor nie będzie obsadzony szwedzką załogą. To - pisali dalej mnisi - co w liście królewskim nazywa się Częstochowa, odnosi się do miasta o tej nazwie, a nie do klasztoru, który wszak nosi nazwę Clarus Mons, i dlatego wymagali, aby miejsce to było pozostawione w spokoju aż do momentu, gdy nadejdą nowe rozkazy królewskie co do przyszłości klasztoru. Zakonnicy obiecywali postapić zgodnie $z$ owymi wytycznymi ${ }^{19}$.

Poza tym - według Müllera - mnisi przestrzegali, że jeśli szwedzki garnizon zostanie wprowadzony do klasztoru, wpływy z odwiedzin wiernych zmniejszą się (ponieważ świętość owej przestrzeni ulegnie nadszarpnięciu), więc przyniesie to mniej niż nic. Paulini wystapili $z$ taką pewnością siebie, gdyż liczyli na ratunek ze strony Polaków oraz także na - kryjących się w lasach - zabijaków wołoskich, którym udało się uciec, choć stracili oni 30-40 ludzi. Wreszcie rzekli sobie mnisi: „keine grosse Menge vor sich und nicht capable Artholerie empfanden [nie stwierdzili żadnej wielkiej ilości przed sobą ani użytecznej artylerii]”.

Szturmowanie wysoko położonego i dobrze opatrzonego klasztoru uważał Müller za niemożliwe, tym bardziej że teren był tu wąski i załamujący się, przy tym zaś skalisty i dlatego do czasu zaminowania grunt zmniejszał szanse oblegajacych. Miejsca nie dało się zdobyć „ausser feuerszwang [wyłącznie mocnym ostrzałem]”, toteż pierwsze dni niczego nie przyniosły: brakowało amunicji oraz większych dział, „ogniowe moździerze” zaś próbowano ściagnąć od Wittenberga z Krakowa. Müller sądził, że Jasną Górę należy zniszczyć i doprowadzić do tego, by stała się ona tym, czym była dawniej: kościołem, do którego ciągną pielgrzymki.

Bardziej pesymistyczny aniżeli cytowany powyżej list Müllera okazywał się ten autorstwa Wrzeszczowicza, wysłany tego samego dnia - 12 XI. Hrabia, który w swej korespondencji krytykował poczynania Müllera, wątpił w możliwość kapitulacji

kiem opuścić klasztor na rewers. Według Kordeckiego w klasztorze przebywali S. Mosiński, N. Krysztoporski, P. Czarniecki, J. Skorzewski i S. Zamojski. [Westrin nie podaje źródła tej informacji - F. M.]. 
miasta „wegen alleley mancamentem [z powodu wielu różnych mankamentów]” i zapewniał: „wen es bei mihr gestanden hette, ich wegen vieler so pollitischen als militärischen rationen diesen orth nicht auf diese Weise attaquiret hette [gdyby to ode mnie zależało, $z$ powodu wielu politycznych i wojskowych powodów nie zaatakowałbym tego miejsca w ten sposób]”. Kończył zaś w te słowa: „Es ruiniren sich totaliter darüber die Regimenter, quartier und das Landt, und man greifet an der Polen Seele und ist zu befürten (was das meist ist) umsonst und vergebens [Rujnują się tym zupełnie regimenty, kwatery i ziemia, atakuje się ducha Polaków i należy się obawiać (co najważniejsze), że to wszystko bez potrzeby i nadaremnie]".

Wittenberg nie mógł w tamtym momencie wysłać do Częstochowy żadnych moździerzy, lecz usiłował pomagać Müllerowi na inne sposoby. W utrzymanym w tonie groźby liście do mnichów wzywał ich do dobrowolnego poddania się. W drugiej połowie listopada wysłał regiment pułkownika [Fromholda] Wolffa, 8 kompanii, które poddały się Szwedom i pod dowództwem Wacława Sadowskiego mogły okazać się użytecznymi podczas ataku, zwłaszcza że Müllerowi brakowało też piechoty. Do tego w ostatnich dniach listopada Wittenberg wysłał dodatkowo 2 „półhakownice” i jeszcze cztery sztuki artylerii innego rodzaju wraz z podpułkownikiem [Fryderykiem] Getkantem - Polakiem, który ze swoimi ludźmi przeszedł pod dowództwo króla szwedzkiego. Wszystko po to, aby w jak największym stopniu przyczynić się do pokonania mnichów. Co więcej, wzmocniono Müllera dwoma regimentami wojsk kwarcianych.

Siły oblegajacych zostały wówczas ostatecznie skompletowane i dostępne źródła pozwalaja je oszacować następująco: siedem kompanii oraz kilka oddziałów kawalerii i dragonów, 11 kompanii piechoty, dwa regimenty wojsk kwarcianych, jak również artyleria z 14 działami, z których dwa były „kartaczami”. Kompanii nie można traktować jako 100 ludzi. Sadowski donosił, że jego regiment nie był kompletny ${ }^{20}$. Ogólnie mówiąc, istnieje wiele dowodów na to, iż jesienią 1655 roku, nim przyszły nowe zmiany wojska i nim przeprowadzono nowe zaciągi, kompanie nie obejmowały więcej niż 60 ludzi ${ }^{21}$. Nawet gdyby zatem szacować kompanię na 100 osób, ledwo można by oceniać, że wszystkie dawały siłę 2000 żołnierzy, nie liczac kwarcianych. Liczebność tych ostatnich jest mi nieznana i w zasadzie nie odegrała żadnej roli, tym bardziej że nie chcieli oni służyć przeciw częstochowskiemu klasztorowi i czynili więcej szkody niż pożytku ${ }^{22}$. Przeciw Częstochowie nie walczył ani jeden szwedzki regiment, a co więcej, najprawdopodobniej też ani jeden szwedzki oficer.

Część szczegółów związanych z przebiegiem działań oblężniczych i ze stoczonymi walkami nie pochodzi z zachowanych dokumentów. Zakonnicy postępowali

Wiadomość ta pojawia się w liście wysłanym z Wielunia 16 XI, w którym W. Sa dow ski pisze na dodatek, że regiment jest wymęczony walkami, i dziwi się, że nie pozwala się żołnierzom odpoczaćc. [Westrin nie podaje źródła listu - F. M.].

21 Rozkaz B. Mülle ra wydany pułkownikowi J. O. de Wahlowi, aby dopełnić regiment ośmioma kompaniami po 60 ludzi każda (26 XI: Zdarzenia zwiazane z wojna polska Karola X Gustawa). Rozkaz Karola X Gustawa, aby zwerbować osiem kompanii kwarcianych, każda po 60 ludzi, z 20 XII. Archiwum Królewskie.

22 A. Witt en berg, list do Karola X Gustawa, z 17 XI. 
odważnie i zręcznie. Wielokrotnie, chcąc zyskać na czasie w oczekiwaniu na pomoc, pozorowali gotowość do podjęcia układów, lecz za każdym razem, gdy wymagano od nich ostatecznych decyzji, wycofywali się. Tygodnie mijały, a Müller nie mógł się dobrać do tych „verwogenen Mönche [rozważnych mnichów]” przez oblężenie, podczas gdy wrogie oddziały rosły w siłę przy śląskiej granicy. To właśnie w związku z zagrożeniem $\mathrm{z}$ tamtej strony Wittenberg zalecił Müllerowi odwrót, jeśli klasztor nie podda się do 17 lub 18 XII. Krótko po tym przyszedł rozkaz królewski z 1 XII o przerwaniu oblężenia i wtedy okazało się, że mnisi nie zamierzają przystać na wpuszczenie szwedzkiego garnizonu do klasztoru. Król motywował swój rozkaz również tym, iż o ile oblężeni mieli się dobrze w murach, o tyle oblegający, ze względu na porę roku, cierpieli niewygody i ponosili ofiary, oraz tym, że przedłużające się oblężenie mogło przynieść niepowetowany „Zu mehreren opiniastritat vielleicht Ursache [uszczerbek na opinii]". Monarcha dostrzegał niebezpieczeństwo wynikające $z$ przedłużającego się zamachu na święte miejsce. Miał świadomość konsekwencji, jakie dla całego narodu ma ranienie jego uczuć religijnych. „Es werden sich sonst auch [A poza tym będą się]" - dodaje Karol Gustaw w postscriptum swego listu - „die Polacken mehr ärgen wegen des Marienbildes attacquirung [Polacy bardziej złościć z powodu ataku na obraz Maryi Panny]”. Müller powinien był zadowolić się tym, że oblężeni złożyli zapewnienia o swym szczerym oddaniu i pełnym wykonaniu postanowień podpisanych w klasztorze, o ile inne królewskie rozkazy nie staną temu na drodze.

Müller wiedział, że oczekiwanie na termin wyznaczony przez Wittenberga nie opłaca się. Wczesnym rankiem 16 XII wyprawił ciężkie działa do Krzepic. Następnego dnia, pod eskortą 300 niemieckich jeźdźców, wysłał kanonierów wraz z amunicją do Krakowa, a tego samego dnia później wyruszył z całą siłą na Piotrków. Po 40 dniach bezowocnego oblężenia odchodził $\mathrm{z}$ ciężkim sercem, trudno było bowiem opuścić pole bitwy, na którym poległo wielu ludzi - zwłaszcza gdy początkowo liczyło się na łatwe zwycięstwo szturmem lub układami. „Vor meine person hatte das Kloster gerne in E. K. M:ts devotion gebracht; seit es aber nicht geschehen, wünsche niemals Darfur gerückelt wehre [Z mojej strony chętnie oddałbym Waszej Królewskiej Mości w ręce ten klasztor, ponieważ do tego jednak nie doszło, nie chciałbym nigdy być za to winiony]" - napisał w liście do króla datowanym na $16 \mathrm{XI}^{23}$.

Był to najwyższy czas dla wojsk Müllera na przerwanie oblężenia: na wschodzie, w okolicach Sandomierza, zaatakowały wojska kwarciane i inne polskie oddziały pod dowództwem Stanisława Potockiego. Już 3 XI wypowiedziały one wierność Karolowi Gustawowi i uderzyły na to miasto, opanowane przez Szwedów pod wodzą generała [Roberta] Douglasa, a następnie ratowały się, wyruszając szybkim marszem na Łowicz ${ }^{24}$. Tam znalazły się 19 XII, a wsie w okolicach Częstochowy już tydzień

23 Wymiana listów między Müllerem a królem była albo opóźniana, albo przerywana poprzez przechwytywanie korespondencji. Wzmiankowany list Müllera z 16 XII najprawdopodobniej nie dotarł do króla przed 26 XII, a przecież tego dnia Karol X Gustaw ponowił rozkaz opuszczenia Częstochowy. Jednocześnie król donosi, że wiele listów Müllera przejęli Brandenburczycy. Wyjaśniałoby to poniekąd, dlaczego tak mało wiemy o dziejach oblężenia. 
po odejściu Müllera zajęło 10000 polskich żołnierzy, którzy wkroczyli ze Śląska i szybko porozumieli się z klasztorem ${ }^{25}$.

Tyle mówią źródła szwedzkie. Popatrzmy teraz, co ojciec Kordecki napisał w swej książce ${ }^{26}$, która 20 XII 1657 otrzymała imprimatur od cenzorów krakowskich, mówiące, że przedstawia ona prawdziwy przebieg wypadków związanych $\mathrm{z}$ atakiem na klasztor i $z$ jego obroną.

Przede wszystkim Kordecki porusza kwestię motywów, jakie przyświecały Karolowi Gustawowi, gdy decydował się on zaatakować klasztor:

Król, zrujnowawszy całe terytorium królestwa, ograbiwszy kościoły ze świętych naczyń i innych drogocenności, uznał za niegodne pozostawienie klasztoru w spokoju przez swych grabieżców ${ }^{27}$.

Skarbów potrzebował na wzmocnienie armii. Pisze Kordecki dalej, że rozkaz do zdobycia Jasnej Góry, nim ostatecznie Müller otrzymał to zadanie, formułowany był trzykrotnie, lecz wówczas za każdym razem wojska były bardziej potrzebne gdzie indziej.

Kordecki wymienia rozmaite detale wiążące się $z$ podjętą przez Wrzeszczowicza próbą zaskoczenia oblężonych. Hrabia pragnął udowodnić królowi swą przewagę nad Müllerem. 30 X o 10 wieczorem niespodziewanie otoczył klasztor, polecił trębaczom pukać do drzwi i wezwał paulinów do złożenia broni, grożąc, że w przeciwnym razie obróci mury i cała posiadłość w popiół. Mnisi odmówili wpuszczenia Wrzeszczowicza. Następnego dnia radził on im, by poddali się jemu - katolikowi, który jest przyjacielem klasztoru i który uszanowałby należące do niego włości zamiast wystawiać się na niebezpieczeństwo wpadnięcia w ręce Müllera, heretyka. Zakonnicy poprosili, żeby poczekać, aż decyzję w tej sprawie podejmie prowincjał, który akurat w tamtym czasie przebywał na Śląsku. Lecz hrabia przedstawił, odtworzona w Nowej Gigantomachii, propozycję układu, która została odrzucona (poddanie się Karolowi Gustawowi, złożenie broni i przekazanie amunicji, wpuszczenie szwedzkiego garnizonu, przejście pod dowództwo Wrzeszczowicza itd.).

Wtedy rozzłoszczony Weyhard podpalił budynek w pobliżu kościoła św. Barba-

J. Pir on w liście datowanym na 30 XII 1655 / 9 I 1656 (Zdarzenia zwiazane z wojna polska Karola X Gustawa). Nie można jednak wykluczyć, że wiadomości pochodzące od Pirona są niesprawdzone bądź przesadzone.

Jest to księga w formacie in quarto, wydana w 1657 r., której pełniejszy tytuł brzmi Nova Gigantomachia, contra sacram imaginem Deiparae Virginis a Sancto Luca depictam et in Monte Claro Częstochoviensi [...] collocatam: Per Suecos \& alios Haereticos excitata et ad perpetuam [...] gloriosae Deiparae Virginis recordationem [...] conscripta.

Cytat ten wydaje się kontaminacją dwóch fragmentów: „Poburzone zamki, wywrócone miasta, szlachta w pęta okuta, nierycerscy i płeć niewieścia żelazem, więzieniem lub sromotną niewolą wyniszczeni. Kościoły świętokradztwem splamione - święte naczynia i sprzęty potłuczone - ołtarze powywracane - swięte obrazy powyrzucane, podarte i spalone [...]” oraz „Po zajęciu Wielkopolski, gdy miał ruszyć ku Krakowu, umyślił: aby napaść na klasztor częstochowski - wysłał więc w tym celu naprzód część wojska z [Hieronimem] Radziejowskim, uważając za korzystne skarbami i sprzętem jasnogórskim powiększyć siły wojenne potrzebne do zdobywania stolicy Rzeczypospolitej”. Zob. A. Korde cki, Nowa Gigantomachia. Pamiętnik oblężenia Częstochowy roku 1655. Przeł. J. Łe p k ow s ki. Warszawa 1858, s. 9, 16. Dalej odsyłam do tego wydania skrótem NG. Liczby po skrócie wskazują stronice. [Przypis tłum.]. 
ry, starł w proch Krzepice - niejako Müllerowi na przywitanie - i namawiał go do przyspieszenia ataku, kusząc klasztornymi skarbami. W tym samym czasie Kordecki wysłał ludzi do Krakowa, aby wywiedzieli się oni, co zamierza przedsięwziąć Wittenberg. Czynili to pod pretekstem prośby o wydanie listu żelaznego, jeśliby się okazało, że jego wystawca rozkazał zaatakować klasztor natychmiast. Jednocześnie Kordecki prowadził prace wokół klasztoru polegające na rozbieraniu budynków znajdujących się zbyt blisko murów obronnych, wzmocnił załogę o doświadczonych żołnierzy, wysłał listy z prośba o pomoc do Jana Kazimierza i do [Stefana] Czarnieckiego, a do tego poprosił pisemnie Wrzeszczowicza i Sadowskiego o opóźnienie ataku. Ten drugi - chociaż luter - próbował zniechęcić Müllera i nie dopuścić do działań militarnych.

Po upływie kilku dni pewien mnich $z$ Wielunia oraz jeden szlachcic poinformowali, że Müller zbliża się na czele 9000 ludzi oraz dodatkowo z 19 oddziałami Wrzeszczowicza, Sadowskiego, księcia Hessen ${ }^{28}$ oraz z dwoma regimentami pod polskimi pułkownikami. Wymienione liczby, oparte na pogłoskach, sa jedynymi informacjami o sile nieprzyjaciela, jakie przytacza Kordecki, jakkolwiek nie mogło mu podczas oblężenia umknąć, że liczby owe były w rzeczywistości znacznie niższe, co też zostało już wykazane ${ }^{29}$. Dane te, dobrze zapamiętane przez Polaków, mogły dać czytelnikom Nowej Gigantomachii fałszywy obraz rozkładu sił - na chwałę oblężonych i na hańbę oblegających - na co Kordecki najpewniej liczył. Ostatecznie zawsze mógł pocieszyć swe sumienie tym, że nie pochodziły one wprost od niego.

Przeor poprawnie opowiada za to, że siły oblężonych zostały już później wzmocnione 700 piechurami $z$ regimentu Wolffa ${ }^{30}$ oraz że Wittenberg wysłał Müllerowi sześć dział. Ten w swych raportach przyznawał się do niejakiej przesady, niemniej twierdził, że załoga klasztorna liczyła 400 doświadczonych żołnierzy. Według Kordeckiego zaś tworzyło ją 70 mnichów, pięciu polskich szlachciców (lecz ich sług nie liczono do ogólnego rachunku) i 160 żołnierzy, „z których większość ledwo co oderwano od pługa" [NG 105-106].

Kordecki wspomina w liście z 8/18 XI, iż Müller odnotował, że klasztor, ze względu na szerząca się rebelię w Wielkopolsce, musi przyjąc szwedzką załogę, aby móc odeprzeć atak (,,adversus quamlibet invasionem [był zmuszony do ich poskromienia]”), i zażądał pertraktacji na temat uporządkowania wszystkich spraw „bez zbędnej zwłoki” [NG 28-29]. Król objął Jasną Górę swą opieką, pisał dalej generał, więc nie powinny mu grozić żaden atak, szkoda bądź obraza. Lecz jeśliby opór się

W roku 1655 przez szwedzką armię w Polsce zatrudnionych było dwóch heskich książąt: graf Friedrich von Hessen-Eschwege, szwagier Karola X Gustawa, oraz graf Kazimierz Wilhelm Hessen-Homburg. Ten pierwszy zginą jeszcze we wrześniu pod Kościanem, ten drugi brał udział w oblężeniu Częstochowy. Którego Kordecki ma na myśli, gdy pisze „książę Hessen”, nie wiadomo. Już u Kobierzyckiego, kompilatora Kordeckiego (Obsidio Clari Montis Częstochoviensis 〈1659〉, s. 39) mówi się: „Non pauciores novem millibus con stat”.

30 Ko r d e c ki pisze, że regiment Wolffa przeszedł w ręce Szwedów, ponieważ Müller przekupił oficerów [NG 53 - F. M.]. Nie jest to prawdą. Zdarzenia przebiegały następująco: gdy regiment ów, za przykładem Czarnieckiego, usiłował przedrzeć się na Śląsk, zaatakowany został pod Będzinem 18 XI przez (wysłany przez Müllera) szwedzki oddział pod dowództwem Sadowskiego. Kompanie otoczyły się taborem i stamtąd się broniły, lecz ostatecznie zmuszone zostały do poddania się. Zob. A. Wit t en ber g, list do Karola X Gustawa, z 20 XI. 
przedłużał, Müller zmuszony byłby zdyscyplinować mnichów, a nawet, w razie konieczności, podpalić klasztor. Dlatego radził „honorowe rozwiązanie” [NG 98-99]. Kordecki - przeciwnie - stał na stanowisku, że to Müller pierwszy zachował się wrogo. Nie dał mnichom szansy na udzielenie odpowiedzi na list - twierdzi przeor a zamiast tego zaatakował wieś Częstochówkę, zajmując pozycje wokół klasztoru i instalując na nich swe siły. Dlatego wystrzelono z dział, by utrzymać przeciwnika na dystans. Wszystkie więc wypadki Kordecki opisuje tak samo jak Müller, z tym wyjątkiem, że według generała to paulini otworzyli ogień przed zajęciem wsi przez Szwedów. Kordecki relacjonuje, iż tego samego dnia wieczorem Müller za pośrednictwem dwóch polskich kapitanów poprosił o zawieszenie broni. Klęli się oni zakonnikom na wszystkie świętości, że nie zaatakują klasztoru zbrojnie. A przecież wiemy, jaką siłą dysponował Müller!

Następnego dnia, tj. 9 XI, generał kazał swej artylerii ostrzeliwać klasztor od strony północnej, lecz stracił przy tym wielu ludzi, gdyż mnisi lepiej celowali, a na dodatek zniszczyli budynki, w których stacjonował wróg. Spowodowało to także ofiary w ludziach. Wysłany przez Müllera polski oficer wzywał do przerwania ognia. Kolejnej doby zakonnicy odpowiedzieli, powołując się na zgodny z prawem mandat Karola Gustawa z 30 IX, zawierający przyrzeczenie zachowania wolności klasztorów i kościołów. Argumentowali, że atak odbywa się wbrew woli monarchy. To podpowiedziało Müllerowi, aby sfałszować oryginał królewskiego listu dotyczący okupacji Częstochowy. Później następuje pełen wykrętów list Kordeckiego z 11/21 XI, w którym próbuje on przekonywać, że rozkaz dotyczył miasta Częstochowa, a nie klasztoru. Porównanie oryginału tego listu, znajdującego się w Archiwum Królewskim i będącego jedynym zachowanym dokumentem $z$ tej wymiany korespondencji między paulinami a dowódcą armii oblężniczej, z wersją włączoną do Nowej Gigantomachii pokazuje znaczne różnice między nimi i wiedzie do stwierdzenia, że albo Kordecki cytował go z pamięci, albo wykorzystał nadarzającą się okazję do wyretuszowania go ${ }^{31}$. Oryginał napisany jest $\mathrm{w}$ tonie pojednawczym $\mathrm{i}$ bez watpienia odnosi się do króla Szwecji; druga wersja zawiera bardziej pokrętny porządek słów: słowo „Szwecja” w ogóle nie pada, zdanie: „Króla Szwecji całe królestwo uznaje i na swego pana wybrało", zostało usunięte, a w jego miejsce pojawiło się sformułowanie tyleż mocne, ile dwuznaczne: „praesidium sufficiens habemus, quo omnis incursio isolentium arceri possit a Loco Sacro [mamy dostateczną załogę do powstrzymania jakiegokolwiek napadu na miejsce święte]". Tu owo poddanie się, słyszalne $\mathrm{w}$ oryginale, równie dobrze może się odnosić do króla polskiego.

Trzydniowy ostrzał z północy i z południa był odpowiedzią rozwścieczonego Müllera, lecz kule albo przelatywały nad klasztorem, albo odbijały się od murów, a niektóre w ogóle do nich nie docierały. Wtedy Piotr Czarniecki poprowadził nocną wycieczkę, którą narobił wiele szkód i zmusił Müllera do przesunięcia szańców na większą odległość.

Następnie wysłano do klasztoru polskiego szlachcica, aby przekonał mnichów do poddania się - lecz ci odmówili. Wówczas Kordecki wysłał do Müllera (co on sam zreszta potwierdza) dwóch braci zakonnych, którzy pod pretekstem rozmów na 
temat kapitulacji Jasnej Góry w gruncie rzeczy mieli za zadanie ocenić siły przeciwnika oraz zyskać na czasie. Szwedzki generał, uważając twierdzę za już zdobytą, spełnił ich życzenie i złożył propozycję układu. Znajdujemy go w Nowej Gigantomachii. Według tej propozycji Jasna Góra zachować miała swe dobra i wpływy, móc w niezakłócony sposób odprawiać ofiary i przyjmować pielgrzymów, a szlachta i załoga - swobodnie opuścić mury; zakonnicy musieliby przyjąć tylko szwedzki garnizon złożony ze 150 ludzi. Ci jednak byliby utrzymywani nie przez mnichów, lecz przez okoliczną ludność, i rozkazano by im stacjonować poza klasztorem. Następnego dnia dwaj paulini przynieśli odpowiedź. Była ona nieoczekiwana - głosiła, że zakonnicy nie mogą wypowiedzieć posłuszeństwa Janowi Kazimierzowi aż do momentu, gdy prymas potwierdzi ważność wyboru Karola Gustawa na króla Polski. Ponieważ wysłannicy w zasadzie nie mieli pełnomocnictwa do negocjowania poszczególnych punktów układu, Müller zaaresztował ich i groził im śmiercią, a w kierunku klasztoru wystrzelono $\mathrm{z}$ działa.

Obrońcy nie ośmielili się odpowiedzieć, bali się bowiem o życie swych towarzyszy. Wtedy zaczęto w spokoju kontynuować prace oblężnicze: kopano rowy strzelnicze, podsypywano szańce, przygotowywano miny. Jednocześnie przybył regiment Wolffa. Aby wyratować posłów, mnisi wielokrotnie wysyłali wiadomość, że gotowi sa przyjać warunki układu, lecz że ich bracia zostali uwięzieni wbrew prawom respektowanym przez cywilizowane narody. Müller zaproponował więc przyjęcie przedłożonych punktów traktatu. Lecz mnisi uznali, że nie mogą ufać tym zapewnieniom, mając przed oczami tak rażący powód, aby nie wierzyć generałowi. Ów wypuścił zatem zakonników. Na to Kordecki zażądał, by król potwierdził warunki układu. Odpowiedziano mu, że nie ma na to dość czasu i że Müller ma wszelkie pełnomocnictwa do tego. Podkreślał on, iż klasztor i tak bronił się dłużej niż Kraków i dzięki temu okrył się wielką sławą. Dodawał też, że paulini nie mogą oczekiwać znikąd pomocy i że szwedzcy wojownicy, którzy opanowali cały kraj, nie odejdą spod murów $\mathrm{z}$ pustymi rękami. W tym samym czasie przyszedł list Wittenberga z 21 XI, który - mówiąc skrótowo - wzywał do przyjęcia szwedzkiego garnizonu pod groźbą wielkich kar. Mnisi zwlekali $z$ odpowiedzią, używając różnych wybiegów. Ostatecznie stwierdzili, że dysponują załogą dość silną, aby odeprzeć każdy, nawet najgroźniejszy atak. Zapewnili, iż królowi umożliwią opanowanie klasztoru, natomiast nie wpuszczą doń żadnego luterskiego bądź kalwińskiego garnizonu.

Wtedy rozpoczęła się trwająca dwa dni wymiana ognia, w której Müller stracił wielu ludzi. Dobre wieści wnet dotarły do klasztoru. 28 XI / 8 XII polski szlachcic, którego generał posłał, aby wezwać mnichów do opamiętania, oświadczył im, że szwedzkie wojsko cierpi wielkie niewygody, że polski regiment myśli o buncie, że Karol Gustaw pociagnął do Prus i że wojska kwarciane przeszły na stronę Jana Kazimierza. Zachęcał więc do wytrwania. To samo czynił konwent mnichów z Krakowa w liście, który przerzucono przez mur, a także jakiś „Scyt” ze szwedzkiego obozu. Mówiło się również o wielkiej liczbie Tatarów zdążających na pomoc Janowi Kazimierzowi. Wszystko to podnosiło oblężonych na duchu pomimo informacji o sześciu działach, które miały nadejść z Krakowa.

Przez kilka dni ostrzał ze strony oblegajacych był raczej słaby. Lecz nagle, sobotniej nocy, rozpoczał się gwałtowny szturm [ze wspomnianych] ciężkich dział przywiedzionych z Krakowa, które niepostrzeżenie zaciagnięto pod mury. Ostrzał 
ten trwał kilka dni, prowadzony z północy i z południa. Kordecki notuje, że w niedzielę doliczono się 340 kul, niektórych nawet 26 -funtowych. Duże kawałki muru odpadły, kilka pokaźnych dział zostało uszkodzonych, byli też polegli. Zaraz po mszy wszyscy, i mężczyźni, i kobiety, i młodzi, i starzy, ruszyli z ochotą do obrony. Przerwano ogień; Müller pytał przez trębacza, czy teraz mnisi przyjmą szwedzką załogę. Ich odpowiedź, że rozważą sprawę dnia następnego, doprowadziła Müllera do furii. Przypuścił on teraz atak na zachodnią stronę klasztoru - najsłabszą. Wielu przekonywało go, że gdyby na samym początku zaatakował właśnie tam, los mnichów byłby przesądzony. W tym czasie jednak zdołali oni wzmocnić ten słaby punkt, przez co dało się go obronić. Następnie skierowano ostrzał znów na wschodnią i północną stronę, w końcu i na południową, a w wyniku bombardowania kościoła mnisi, którzy właśnie odprawiali mszę, musieli uciekać.

Propozycja wprowadzenia w mury katolickiego garnizonu pod dowództwem księcia Hesji, także katolika, została odrzucona.

Pomimo trudnego terenu cały czas prowadzono intensywne wysiłki, aby uczynić podkop i podłożyć minę. Müller kazał sprowadzić minerów. Pracowali oni na zmiany dzień i noc, drążąc skałę, na której stoi klasztor, i zbliżali się od strony wschodniej, tak że mówiono, iż założenie zostanie wysadzone w powietrze. Nowa wycieczka, poprowadzona w środku dnia 10/20 XII przez Stefana Zamojskiego, przerwała prace minerów. Ludzi wycięto, zniszczono też kilka armat i działania oblężnicze musiały zostać wstrzymane. Na trzeci dzień przybyły wozy z Krakowa, dostarczając proch i uzbrojenie, co przysporzyło oblężonym niemało zmartwien. W klasztorze zapanowało przekonanie, że wróg przygotowuje przerażający atak, że szykują się drabiny, maszyny oblężnicze, granaty itd.

14/24 XII, gdy oblężeni obchodzili Wigilię Świąt Bożego Narodzenia, Müller znów posłał list, w którym obwiniał mnichów o to, że raz za razem popełniają oni występek przeciwko królowi i przeciwko niemu samemu poprzez zwodzenie i udawanie gotowości do zawarcia układu, i po raz ostatni wezwał ich do poddania się. Czynił ich odpowiedzialnymi przed Bogiem, królem i całym chrześcijaństwem za ich upadek i zniszczenie klasztoru, a zakończył wezwaniem do natychmiastowej odpowiedzi, gdyż wszystko było już gotowe do ostatecznej rozprawy. Kordecki, który dowiedział się, że Jan Kazimierz przekroczył granicę śląską, aby połączyć się z Tatarami, napisał w odpowiedzi, że wystawił cierpliwość Müllera na próbę, lecz uczynnił to z obawy o to, że jego zgodliwość naraziłaby klasztorna immunitas. Mnisi chętnie zawarliby jednak układ, pod warunkiem że czas świąteczny nie zostanie zakłócony. Kordecki zażądał zawieszenia broni i przyrzekł, że gdy tylko uzyska zezwolenie przełożonych, zrobi to, co należy. Jednocześnie zawarował sobie listownie u Wrzeszczowicza, aby ten poparł jego prośbe u Müllera. Wrzeszczowicz ripostował krnąbrnym zakonnikom, iż Müller przyrzekł nie zakłócać świątecznej mszy, jeśli jeszcze w czasie wigilijnym zobowiążą się oni do podjęcia rozmów w drugi dzień świąt. W przeciwnym razie upadek klasztoru nastapić miał tej samej nocy lub kolejnego dnia. Ultimatum pozostało bez odpowiedzi.

Mnisi nie położyli się spać przez całą noc, lecz nic nie słyszano o jakichś działaniach zbrojnych ani wtedy, ani następnego dnia przed południem. Natomiast po południu pierwszego dnia Świąt aż do wieczora trwał ostry ostrzał, podczas którego użyto ognistych kul. Kule te bardziej szkodziły oblezżonym poprzez smród, jaki 
wydawały, aniżeli przez groźne płomienie, które niosły, mimo to jednak czyniły mało szkody, podobnie jak granaty. To była ostatnia bitwa.

Tego samego dnia wieczorem Müller przekazał mnichom i szlachcie pismo, w którym zostawiał im wybór: albo do następnego dnia złożyć broń, albo - ostatecznie zawodząc zaufanie Karola Gustawa - bezzwłocznie zapłacić odszkodowanie za przedłużający się opór i szkody wyrządzone klasztorowi i okolicy (zakonnicy 40000 talarów, wysoko urodzeni 20 000). Jeśliby żadna $z$ tych propozycji nie została zaakceptowana, oblężenie miało zostać częściowo zawieszone, lecz dobra klasztorne w promieniu trzech mil - przejęte na rzecz skarbu królewskiego, podobnie jak dobra szlachty znajdującej się w klasztorze. Samym jego obrońcom zapowiadano zaś „los podobny do tego, który spotkał Buzyrysa na ołtarzu lub Perillusa w byku sycylijskim" ${ }^{2}$. Drugiego dnia świąt Kordecki odpowiedział, że gdyby okupu zażądano na początku, zakonnikom byłoby łatwiej wypłacić taką sumę, lecz teraz, gdy włości klasztorne zostały zniszczone ogniem i mieczem, nie ma ku temu możliwości. Mnisi, zdaniem przeora, nigdy nie występowali przeciw królowi szwedzkie$\mathrm{mu}$, poza tym zażądali pozostawienia w klasztorze polskiej załogi, argumentując, że jest to najmniej kosztowne rozwiązanie. Kordecki twierdził, iż oni sami żyją w najgłębszym ubóstwie, więc świętemu miejscu wyrządzono grubą niesprawiedliwość, Müller zaś powinien łączyć z klasztorem lepsze myśli, ulitować się nad mnichami, a wtedy oni będą się modlić o Boże błogosławieństwo dla niego.

Drugiego dnia świąt mieszkańcy Jasnej Góry składali sobie nawzajem życzenia pomyślności - grała muzyka, strzelano z dział i broni ręcznej. Zdesperowani Szwedzi zaczęli jeszcze tej samej nocy odwrót spod murów klasztornych, zrozumieli bowiem, że nie zwyciężą w miejscu, w którym panuje taki duch i w którym jest pod dostatkiem prochu - powiada Nowa Gigantomachia.

$Z$ przekonania lub raczej $z$ chęci wywyższenia swego klasztoru przeor przypisuje jego ocalenie bezpośredniej ingerencji Najświętszej Marii Panny. Konstatuje, że to ona pomagała mnichom celować $z$ dział, to ona sprawiła, że kule odbijały się od murów i ona wywoływała w najeźdźcach przerażenie. Można by owe zdarzenia przytaczać jako dowody czynienia cudów w procesie kanonizacyjnym Kordeckiego. Jak przecież wiemy, oblężenie nie powiodło się ze względu na położenie klasztoru i jego dobre umocnienia, a w dalszej kolejności - w efekcie zaszłości natury politycznej oraz pod wpływem ogólnej sytuacji na frontach tej wojny. Trzeba jednak dodać także, że dowództwo obrony bardzo przyczyniło się do utrzymania Jasnej Góry. Dowództwo, czyli Kordecki, który objawił nadzwyczajne połączenie płomiennej wiary, zimnej kalkulacji, umiejętności praktycznego działania, świetnej retoryki i dzielności. Jego zadanie było trudne ze względu nie tylko na wrogów, ale i na ludzi zamkniętych razem $\mathrm{z}$ nim $\mathrm{w}$ murach podczas oblężenia. $\mathrm{W}$ grupie naczelnej panowało w gruncie rzeczy ogromne niezdecydowanie. Wielokrotnie jedynie w wyniku plotek o tym, że Müller atakuje, słabła odwaga oblężonych. Niektórzy uważali, iż głos 
mnichów ma zbyt wielki wpływ: Kordecki przekonał ich, aby zginęli w imię Matki Bożej, co miało sprawić, by z poświęconego jej klasztoru błogosławieństwo popłynęło na cały naród polski. Niektórzy ludzie $\mathrm{z}$ załogi chcieli się poddać - tym podwojono żołd. Część szlachty, zmęczona trudami przedłużającego się oblężenia, także myślała o złożeniu broni - tych pytano, czy łudzą się, że ujdą z życiem $z$ objętego pożogą zwyciężonego klasztoru, i jednocześnie wskazywano, iż nadchodzi pomoc ze strony Jana Kazimierza. Przekonanie o tym oraz wiedza, że prowadzenie zimowego oblężenia graniczy z niemożliwością utwierdzały Kordeckiego w chęci wytrwania.

To, iż atak był błędem, którego popełnienie przyniosło nie tylko hańbę odwrotu, wydawało się oczywiste. Sam Kordecki uważał szczęśliwą obronę Jasnej Góry za dany Polakom znak z niebios zwiastujący pomyślność $\mathrm{w}$ dalszej walce $\mathrm{z}$ wrogiem. Przywoływał przy tym Gedeona, który domagał się znaku, że Pan będzie z nim razem w boju, aż ujrzał ziemię pokrytą rosą i suche owcze runo leżące pośrodku.

Atak na świątynię, w której znajdował się obraz Matki Boskiej - choć został wywieziony w bezpieczne miejsce na dzień przed nadejściem Wrzeszczowicza - naprawdę był ciosem zadanym polskiej duszy (by użyć słów samego hrabiego), naród więc $z$ bijącym sercem śledził losy oblężenia i $z$ ufnością czekał na jego koniec szczęśliwy dla obrońców. W dokumentach konfederacji zawartej w grudniu 1655 między szlachtą a wojskami kwarcianymi w celu obrony ojczyzny atak na Częstochowe wymieniany był jednym tchem jako „hoc in Deum et ejus Sanctissimam Matrem pietatis nostrae fundamentum [atak na Boga i Jego Przenajświętszą Matkę, fundament naszej pobożnościl", wezwanie do podniesienia broni. Kordecki twierdzi, że był to "główny motyw” (potissimum motivum) ku temu [NG 136].

Dla uczestników powstania, które po zwycięstwie mnichów wybuchło w Wielkopolsce i w Małopolsce, Częstochowa stanowiła jakby bazę operacyjna. Gdy pod hasłem oporu przeciw Szwedom Jan Kazimierz składał śluby lwowskie 1 IV 1656 i gdy klękał przed ołtarzem maryjnym w katedrze w Lembergu ${ }^{33}$, wobec świeżo doznanej łaski zawierzył swe ziemie Marii Pannie i nazwał ją „Królową swego królestwa” [NG 8].

Kordecki opowiada o jeszcze trzech szwedzkich próbach zdobycia Częstochowy: jednej w styczniu, jednej w lutym i jednej w kwietniu 1656 - tej pierwszej na rozkaz Müllera, dwóch następnych zaś pod dowództwem Wrzeszczowicza. Szwedzkie źródła na ów temat milczą. Najprawdopodobniej próby te stanowiły jedynie rekonesanse (co nie wyklucza, że liczono też na ewentualne zaskoczenie przeciwnika). W każdym razie takim rekonesansem było podejście styczniowe, bo o nim raportował Müller królowi 21 I 1656.

Co prawda, Nowa Gigantomachię przenika punkt widzenia polskich patriotów, jak też katolicka nienawiść do wrogów wiary i narodu, jednak sposób przedstawienia wydarzeń $\mathrm{i}$ ich przebiegu sprawia wiarygodne wrażenie (naturalnie $\mathrm{z}$ wyjątkiem cudów). Oczywiście z zastrzeżeniem, że wiele nieprawdziwości rzuca się w oczy. Nawet włączone do tekstu źródła ${ }^{34}$, które w największej mierze decydują o wartości pismo Karola Gustawa, pismo Wittenberga, listy J. Kalińskiego i Sadowskiego do przeora (z listopada, grudnia i stycznia). 
książki jako dokumentu historycznego, przy porównaniu z oryginalnymi dokumentami (tam, gdzie to możliwe), ukazują kilka wielkich niezgodności, generalnie jednak pokrywając się co do ogólnej wymowy. Nowa Gigantomachia powinna być więc traktowana jako dobre źródło pełnej wiedzy o wydarzeniach historycznych. Nie można dopuścić, by pozostały one nieznane w naszych podręcznikach do historii. Zasługują na powszechne zapamiętanie, jeśli nie poprzez swą doniosłość polityczną i militarną, to $z$ pewnością $\mathrm{w}$ związku $\mathrm{z}$ ważnością, jaką miały i wciąż mają dla narodu polskiego - dla jego wyobrażeń i literatury, co skądinąd stało się dla nas oczywiste dzięki cytowanej już tu książce pana Jensena. Nazwa „Częstochowa” nie powinna pozostawać nieznana dla wykształconego Szweda.

Gdy ksiądz Kordecki zajęty był pisaniem Nowej Gigantomachii, trafiła do jego rąk jeszcze jedna publikacja przesłana z Francji Janowi Kazimierzowi. Znacznie wzmogła ona jego oburzenie na wrogów klasztoru. Była to relacja o tym, jak Karol Gustaw, sprzymierzony z Jerzym II Rakoczym i Kozakami, pokonał we wstępnym boju wojska [Stefana] Czarnieckiego wycinając 20000 jego ludzi, a następnie 16 IV 1657 wszyscy oni ruszyli na Częstochowę, która po kilku dniach ostrzeliwania wzięli szturmem, po czym dokonali przerażającej rzezi mnichów, księży i ludzi świeckich, a także splądrowali klasztorne kosztowności. Kordeckiemu przybył przez to nowy kłopot, o czym pisze on w liście z 23 IV tego samego roku, podkreślając, że relacja została wydana w Amsterdamie oraz w innych miejscach. Ojciec ma słuszność wyszła nawet po szwedzku ${ }^{35}$ i zawiera w połowie Wyciag z pism Generała Majora Wurtzburga do Jego Książęcej Mości Ekscelencji Feldmarszałka Douglasa, datowany w mieście Cz[ę]stochowa 23 kwietnia Anno Domini 1657, a w połowie Nieszczęście Gdańska 5 maja 1657. Druk jest fałszywą kroniką bitew i zwycięstw, nierzadką w tamtych czasach, a i dziś pozostająca w modzie. Zadziwia fakt, że mamy po szwedzku relację o bohaterskim podboju klasztoru, do jakiego nigdy nie doszło, a nie mamy rzetelnego sprawozdania o 40-dniowym oblężeniu, które było bezsensowne i nieudane. We wskazanym czasie nie podjęto żadnej próby zdobycia Jasnej Góry. Król Karol Gustaw znajdował się wtedy daleko od Częstochowy, w okolicach Zawichostu, w widłach Sanu i Wisły, gdzie szwedzkie wojska zajęte były budową przeprawy promowej przez rzekę ${ }^{36}$.

Nie ma sensu przytaczać tu wszystkich, pełnych świętego oburzenia, słów, jakimi Kordecki nasyca swą wypowiedź na opisywany temat. Stwierdza m.in.:

Bezbożny naród szwedzki, rzuciwszy do walki tysiące, nie poradził sobie z Częstochową i nie starł jej w proch, za to napełnił świat obrzydliwymi kłamstwami, co przynosi mu hańbę w oczach świata. [NG 146 - F. M.]

\section{I z usprawiedliwioną dumą woła:}

Mons Clarus Częstochoviensis i jej klasztor, który święci z uwielbieniem imię przeczystej Matki Bożej, stoi nienaruszony na wieczną obrazę szwedzkiej bezbożności [NG 147 - F. M.] ${ }^{37}$.

Ze szwedzkiego przełożył Filip Mazurkiewicz

Wyd. 15 V 1657 na ośmiu kartach in octavo pt. Uthförligh Berättelse om then Herliga Victorien [...]. Zob. dziennik Dahlbergha.

Podczas polskiej wojny Karola XII w 1703 r. powstał plan zdobycia klasztoru jasnogórskiego. Mimo częściowego wdrożenia tego planu w życie do ataku ostatecznie nie doszło. 


\title{
ANEKS \\ List przeora Augustyna Kordeckiego do generała Burcharda Müllera von der Lühnena z dnia 11/21 XI 1655 w wersji z Archiwum Królewskiego i z Nowej Gigantomachii
}

\author{
Oryginał listu ks. Augustyna Kordeckiego do generała Burcharda Müllera \\ odnaleziony w Archiwum Królewskim ${ }^{38}$
}

Noverit Illustrissima et Excellentissima Dominatio religiosam vocationem nostram non habere ius eligendi Reges, sed electos a proceribus regni venerari. Quia igitur serenissimum Regem Suesiae totum regnum sequitur, et in dominium suum elegit, ideo et nos cum loco nostro sacro, qui hucusque sicut in protectione, ita et in sum ma veneratione regum Poloniae habitus, humiliter submisimus Sacrae Regiae Maiestati Sueciae; testantur literae Saluae guariae Illustrissimi et eccellentissimi Domini Vitembergii Supremi generalis conceptae Monasterio nostro de dato 28 Octobris. Renouauimus iterum nostram submissionem nouis datis Varsauiam literis, super quas benignum a Clementissimo Domino expectamus responsum. Veneramur igitur tanquam submissi subditi Serenissimam Regiam Maiestatem Sueciae, Dominum Nostrum Clementissimum, noque ulla arma offensiua contra exercitum Serenissimi Regis mouere molimur. Vidimus ordinationem Serenissimi Regiae Maiestatis, sed quoniam Monasterium nostrum una cum Ecclesia diuersa antiquities gaudeat denominatione et conceptur Clarus Mons, oppidumque Częstochowa ad Nostrum Monasterium nulla ratione pertineat, ideo nobis multampeperit ambiguitatem. Quare obnixe Suae Ilustrissimae et Excellenissimae Dominationi supplicamus, Conventum Nostrum, Ecclesiam Deo et eius Sanctissimae Matri Sacrum, in qua Maiestas Diuina pro incolumitate Serenissimi Regis Sueciae Domini et Protectoris Regni Nostri exoratur, nosque quorum vocativo non est potentine Regum resistere, veli in pace delinquere, quodusque non fuerit sublata ambiguitas per nouam Sacrae Regiae Maiestatis Sueciae resolutionem. Non aspernamur Excelintissimam Dominationem, de cuius protectione multum et in posterum nobis policemur. Quidquid Sua Regia Maiestas imperauerit, libenter faciemus. Interim nos fauori Ilustrissimae et Excellentissimae Dominationisquam diligentissime commendammo.

Ilustrissimae et Excellentissimae Dominationis vestrae humillimus in Christo servus et exorator indignus

\section{Fr[ater] Augustinus Kordecki Prior Clari Montis}

[Niechaj się dowie Szanowna i Szlachetna Dostojność Wasza, że nasz stan zakonny nie posiada prawa wybierania królów, lecz czci tych, których szlachta królestwa wybrała. Ponieważ Jego Królewską Mość, Króla Szwecji całe królestwo uznaje i na swego pana wybrało, przeto i my z naszym miejscem świętym, które do tego czasu tak opieki, jak i najwyższego poszanowania doznawało ze strony królów polskich, pokornie poddaliśmy się Jego Królewskiej Mości [Króla] Szwecji; świadczy o tym list salwagwardii szanownego i szlachetnego pana Wittenberga, naczelnego wodza, danej naszemu klasztorowi, dnia 28 października; odnowiliśmy naszą submisję powtórnie, wysyłając do Warszawy pismo, na które od Jego Królewskiej Mości oczekujemy odpowiedzi. Czcimy więc, jako ulegli poddani, Jego Królewską Mość [Króla] Szwecji, Pana naszego najłaskawszego, nie odważamy się też podnieść zaczepnego oręża przeciw wojsku Jego Królewskiej Mości. Widzieliśmy rozporządzenie Majestatu Królewskiego, lecz ponieważ

Polskie tłumaczenie za: L. Frą ś, Obrona Jasnej Góry w roku 1655. Częstochowa 1934. Współczesna weryfikacja tłumaczenia - M. Haykowski w 1996 roku. Ten i kolejny przekład na stronie: http://eurofresh.se/manuskrypty/kordecki (data dostępu: 1 III 2019) List przeora Kordeckiego znajduje się w Archiwum Królewskim pod sygn. SE/RA/720049/ / 1. Jest także zdigitalizowany i dostępny pod adresem: http://sok.riksarkivet.se/bildvisning/R0001325_00003\#?c $=\& \mathrm{~m}=\& \mathrm{~s}=\& \mathrm{cv}=2 \& \mathrm{xywh}=-1735 \% 2 \mathrm{C}-426 \% 2 \mathrm{C} 5803 \% 2 \mathrm{C} 3313$ (data dostępu: $20 \mathrm{~V}$ 2019). [Przypis tłum.]. 


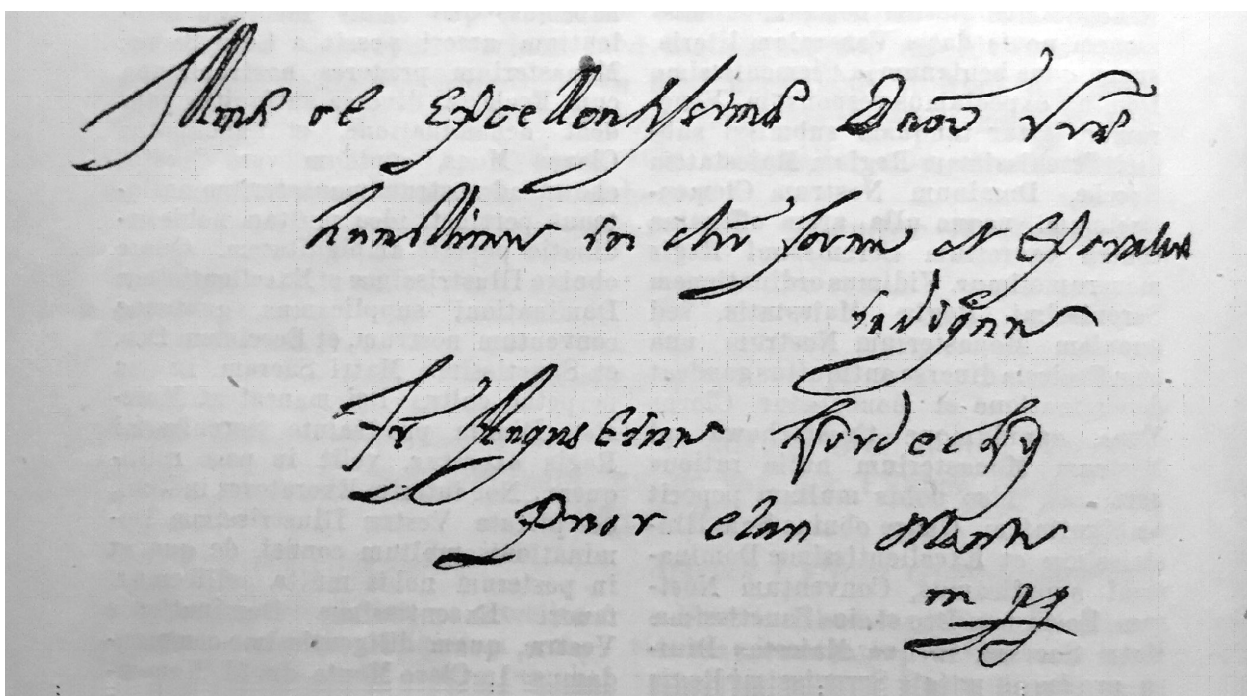

Autograf Augustyna Kordeckiego odbity z oryginału listu

klasztor nasz wraz z kościołem $z$ dawien dawna inna posiada nazwę i nazywa się Jasna Góra, a miasto Częstochowa pod żadnym względem nie należy do klasztoru, rozporządzenie wspomniane wielką obudziło w nas wątpliwość. Dlatego uniżenie szanownego i szlachetnego Pana prosimy, ażeby dopóki ta wątpliwość nie zostanie usunięta przez nowe rozstrzygnięcie Jego Królewskiej Mości, tak nasz klasztor i poświęconą Bogu i Jego Najśw[iętszej] Pannie świątynię, w której się zasyła do Boskiego Majestatu modlitwy za zdrowie Najjaśniejszego Króla Szwecji, Pana i Protektora naszego królestwa, jak i nas samych, których bynajmniej nie jest powołaniem opierać się potędze królów, zechciał w pokoju zostawić. Nie uwłaczamy przez to szlachetnemu Panu, lecz owszem od Jego poparcia i w przyszłości wiele sobie obiecujemy. Cokolwiek Jego Królewska Mość rozkaże, chętnie spełnimy. Tymczasem jak najusilniej polecamy się łaskawości szanownego i szlachetnego Pana.

Brat Augustyn Kordecki Przeor Jasnej Góry]

\section{List ks. Augustyna Kordeckiego do generała Burcharda Müllera według tekstu zamieszczonego w Nowej Gigantomachii (1657)}

Noverit Illustrissima et Excellentissima Dominatio Vestra, non esse vocationis nostra, Reges eligere, sed electos a Proceribus Regni venerari: quem igitur Proceres Regni eligunt, et Locum hunc Sacrum, qiu hucusque perpetuo sicut in protecciones, ita et in venerazione summa Regum fiut habitus, humiliter submittimus, et submittemus, non manu armata coacti (neque enim vocationis nostrae aut virium est, potentiae regum resistere), sed nostra religiositate commenti. Vidimus ordinationem Serenissimae Majestatis: et quoniam praesidium sufficiens habemus, quo omnis incrussio insolentium arceri possit a Loco Sacro; Monasterium praeterea nostrum, una cum Ecclesia, diversa antiquitus gaudeat denominatione, et nuncupatur Clarus Mons, oppidum vero Częstochowa, ad nostrum monasterium nullatenus pertinet, ideo multam nobis ordinatio peperit ambiguitatem. Quare obnixe Illustrissimae et Excellentisimae Dominationi spuulicamus, quatenus conventum nostrum, et Ecclesiam Deo, et Sanctissimae Matri Sacram, in qua perpetuo cultus Dei magnet et Maiestas Diuina pro salute Serenissimi Regis exoretur, veli in pace delinquere. Nos interim Exoratores indigni, de pietate Vestrae Illustrissimae Dominationis multum confisi, de qua, et in posterum nobis multa pollicemur, fauori Excentissime Domi- 
nationis Vestrae, quam diligentissime commendammo. In Claro Monte, die 21. Nouembris, Anno Salutis 1655. F[rater] A[ugustinus] K[ordecki] P[rior] C[laro] M[ontis].

[Niechaj się dowie szanowna i szlachetna Dostojność Wasza, iż nie jest naszym powołaniem wybierać królów, lecz wybranych przez szlachtę szanować. Kogo szlachta wybiera i uznaje, temu i my samych siebie i to miejsce święte, które do tego czasu doznawało tak opieki, jak i najwyższej czci ze strony królów, poddajemy pokornie i poddawać będziemy, chociaż nas do tego nie zmusza oręż (opieranie się bowiem potędze królów nie zgadza się z naszym powołaniem i nie mamy sił po temu). Widzieliśmy rozporządzenie Jego Królewskiej Mości, ale ponieważ mamy dostateczną załogę do powstrzymania jakiegokolwiek napadu na miejsce święte, a klasztor nasz wraz z kościołem $z$ dawien dawna inną posiada nazwe i nazywa się Jasna Góra, a miasto Częstochowa wcale do klasztoru nie należy, wspomniane rozporządzenie wielką obudziło w nas wątpliwość. Dlatego usilnie szanowną i szlachetną Waszą Dostojność prosimy, ażebyś nasz klasztor i poświęconą Bogu i Najśw[iętszej] Pannie świątynię zostawił w pokoju, aby w niej trwała wieczna chwała Boża i aby w niej proszono Majestat Boży o zdrowie Jego Królewskiej Mości. My tymczasem, zanosząc nasze prośby, polecamy się najusilniej łaskawym względom Waszej Dostojności, pokładając ufność w Jego dobroci, po której i na przyszłość wiele sobie obiecujemy. Na Jasnej Górze, dnia 21 listopada Roku zbawienia 1655. B[rat] A[ugustyn] K[ordecki] P[rzeor] J[asnogórski]].

Abstract

\title{
THEODOR WESTRIN
}

\section{ON THE 1655 SIEGE OF JASNA GÓRA MONASTERY BY THE ARMY OF CHARLES $X$ GUSTAV}

\author{
Translated and edited by \\ FILIP MAZURKIEWICZ University of Silesia, Katowice \\ ORCID: 0000-0003-0702-4147
}

Theodor Westrin's study was published in 1904 and is presumably an answer to Henryk Sienkiewicz's growing international fame crowned by the Nobel Prize the writer was awarded with in 1905. Westrin gives a survey of Swedish historical sources referring to the siege of Jasna Gora Monastery, and then compares them with the Polish accounts on the subject, primarily with Abbot Augustyn Kordecki's Nowa Gigantomachia (New Gigantomachia). Thus the reader finds here many protagonists well known from Henryk Sienkiewicz's Potop (Deluge); apart from Kordecki, also General Burchard Müller, Count Jan Weyhard Wrzeszczowicz, Marshall Arvid Wittenberg, and ultimately the kings-the Polish and the Swedish. One of the main myths of Polish history debugs here, while many elements of the accounts of the siege to which we got accustomed or which we regard as trustworthy became half- or untrue. 